\author{
В.А. Семаль, В.Г. Трегубова, О.В. Нестерова
}

\title{
СОСТАВ ПОЧВЕННОГО ПОКРОВА ЮГО-ВОСТОЧНЫХ МАКРОСКЛОНОВ СИХОТЭ-АЛИНЯ (НА ПРИМЕРЕ ЛАЗОВСКОГО ЗАПОВЕДНИКА ИМ. Л.Г. КАПЛАНОВА)
}

В настоящее время практически все почвы в Приморском крае в той или иной степени подвержены антропогенному влиянию (используются под пашни, мелиоративные системы, строительство, добычу полезных ископаемых, лесозаготовку), что приводит к изменению свойств почвы, ее морфологии и, как следствие этого - к деградации. Становится трудно определить особенности генезиса почвы, проследить эволюцию почвенного покрова. Почвы Лазовского заповедника не подвержены антропогенному воздействию и отражают специфические черты функционирования экосистем южного Сихотэ-Алиня. Почвы юго-восточных макросклонов Лазовского заповедника уникальны как по морфологии и свойствам, так и по местоположению и находятся в ненарушенном состоянии, их можно использовать как природный эталон для сравнения с измененными человеком аналогами. В связи с этим необходимы инвентаризация и изучение свойств почв, важных для специалистов различного профиля с точки зрения экологии почв.

Представленный материал является составной частью исследования фундаментальной проблемы - развития и эволюции почв Дальнего Востока. Необходимость изучения естественных вариантов типичных для данных условий экосистем почв с соответствующим оригинальным почвенным покровом в качестве «эталонов» - образцов поможет получить сравнимые оценки состояния окружающего почвенного покрова, прогнозирования направления и скорости его изменения, для сравнения с нарушенными при антропогенном воздействии аналогами.

Территория Лазовского заповедника располагается на южных отрогах Сихотэ-Алиня и занимает вытянутый в меридиональном направлении хребет Заповедный, делящий охраняемую территорию на две части: северную континентальную и южную - приморскую. Сильно пересеченный рельеф, большая крутизна склонов делает территорию заповедника труднодоступ- 
ной. Отсутствие почвенных материалов на территории заповедника определяют новизну исследования и вызывают интерес к почвенной составляющей заповедника. Природные комплексы уникальных лиановых хвойношироколиственных и пойменных широколиственных лесов Лазовского заповедника обладают высокой биопродуктивностью и биоразнообразием.

Целью исследования является изучение почв и почвенного покрова юго-восточных макросклонов юга Сихот-Алиня на примере Лазовского заповедника.

Состав почвенного покрова и закономерности распределения почв в пространстве были изучены методом ключей и методом заложения почвенно-геоморфологических профилей. При определении почв была использована классификация почв России и WRB [1, 2].

Своеобразие физико-географического положения Лазовского заповедника на территории юга Приморья, разнообразие экологических условий формирования почвенного покрова предопределяет наличие большого спектра почв, представленных в основном почвами буроземного ряда.

Пространственное размещение почв Лазовского заповедника подчиняется закономерностям, прежде всего связанным с горным характером территории: экспозицией и крутизной склонов, высотой горных отрогов, составом биоценозов. Основными факторами классификационной дифференциации почвенного покрова заповедника являются положение почвы в рельефе, пестрота растительного покрова и характер покровных отложений. Специфика горного почвообразования и оригинальность почв горных территорий обуславливает своеобразие зависимости почв от горной породы, повышенной гумусности, преобладание стока над просачиванием.

В почвенном покрове Лазовского заповедника преобладают буроземы, формирующиеся на разных по литологии почвообразующих породах под разными типами растительности. По характеру проявления основного и сопутствующих ему процессов буроземы подразделяются на подтипы: типичные, грубогумусированные, эродированные (абраземы структурнометаморфические), оподзоленные. Другим типом буроземов являются буроземы темные, в которых выделяются подтипы: темные типичные, темные глееватые, остаточно-карбонатные.

При относительном однообразии почвообразующих пород на формирование почв особенно большое влияние оказывает рельеф (крутизна и экспозиция склона). Почвообразующими породами для почв горной тер- 
ритории является элювий средней и сильной степени выветрелости гранито-гнейсов, на склонах перекрытый маломощными делювиальными отложениями, пойма сложена морским и речным аллювием.

В почвенном покрове низкогорий можно выделить две группы почв, относящихся к одному генетическому типу, но отличающихся разнообразием морфологического строения почвенных профилей. Под малотравными дубовыми лесами с плохо развитым кустарниковым ярусом формируется первая группа почв - буроземы, отличительной чертой которых является малая или средняя мощность гумусо-аккумулятивного горизонта и высокая степень оглиненности минеральной толщи. Профиль этих почв слабо дифференцирован на генетические горизонты. Метаморфический горизонт Вm имеет тяжелый механический состав и ярко-бурую окраску, что характерно для буроземов более континентальных районов юга Дальнего Востока. Почвы подобного строения имеют наибольшее распространение на территории исследования. Они приурочены, в основном, к склонам, покрытыми щебнисто-мелкоземистыми делювиальными отложениями. Локально, в местах произрастания тонкоствольных дубняков с полностью отсутствующим кустарниковым ярусом, но с хорошо развитым высокотравным напочвенным покровом формируется вторая группа почв буроземы, отличающиеся малой мощностью почвенного профиля и сильной его щебнистостью. Однако морфологическое строение этих почв обнаруживает определенное своеобразие, заключающееся в наличии хорошо развитого, довольно мощного гумусово-аккумулятивного горизонта с мюллевым гумусом. Существование его обязано, очевидно, богатому ежегодному опаду, состоящему из трав, сравнительно быстроразлагающемуся в условиях довольно высоких среднегодовых температур.

По каменистости почвы элювиальных ландшафтов глубококаменистые, почвы трансэлювиальных ландшафтов неглубоко- и поверхностнокаменистые, трансаккумулятивных - неглубоко- и глубококаменистые. Почвы аккумулятивных ландшафтов северо-западной экспозиции поверхностнокаменистые, а юго-восточной - глубококаменистые. Суммарная мощность почвенной толщи (солума) вне зависимости от экспозиции не превышает одного метра.

Буроземь типичные (Haplic Cambisols (Sceletic)) занимают наибольшие в процентном отношении площади и формируются на крутых склонах и вершинах сопок, на водоразделах, на высоких речных тер- 
pacax, то есть на поверхностях с достаточно мощными, хорошо дренируемыми щебнисто-мелкоземистыми рыхло упакованными покровными отложениями под широколиственными и кедрово-широколиственными лесами. На поверхности отмечается свежий растительный опад, под ним, как правило, лежит подстилка (органо-перегнойный горизонт), иногда слоистая, состоящая из растительных остатков разной степени разложенности. Для этих почв характерны как маломощные, так и мощные подстилки гумифицированного типа, слабая дифференциация на генетические горизонты, сильная щебнистость. Аккумулятивный гумусовый горизонт имеет темно-серый с буроватым оттенком цвет. Этот горизонт мощностью $10-$ 15 см, обычно рыхлый, рассыпчатый, густо пронизан корнями, с хорошо выраженной комковато-зернистой структурой, прикрепленной к корневым волоскам. Этот горизонт чаще легко-, реже среднесуглинистый. В верхней части горизонта отмечается повышенное содержание древесного угля, в значительной степени определяющего его серовато-черную окраску. Окраска иллювиально-метаморфических горизонтов варьирует от бурой с коричневым оттенком до буро-желтой. С глубиной она светлеет и постепенно приобретает цвет почвообразующей породы. По гранулометрическому составу почвы легкосуглинистые в верхней части профиля и средне- и тяжелосуглинистые в нижней. На сильно крутых склонах и на узких гребнях сопок буроземы типичные сочетаются с петроземами гумусовыми, которые распространены на территории каменистых россыпей.

Буроземы типичные имеют кислую или сильнокислую реакцию среды. В средней и нижней части профиля обычно реакция среды более кислая, чем в гумусово-аккумулятивном горизонте. По содержанию и распределению гумуса по профилю буроземы типичные можно разделить на две группы. К первой группе принадлежат почвы с маломощным гумусовоаккумулятивным горизонтом (11-12 см) и высоким содержанием гумуса в нем (23-26 \%). В подгумусовых горизонтах содержание гумуса резко падает. Во второй группе почв распределение гумуса по профилю постепенное и содержание его в верхнем горизонте не такое высокое (9-13\%). По качественному составу гумуса эти почвы также имеют некоторые различия. $\mathrm{У}$ буроземов первой группы гумус в верхних гумусовоаккумулятивных горизонтах в основном гуматный, а в нижележащих горизонтах - гуматно-фульватный и фульватный. У буроземов же второй группы нет такой резкой дифференциации гумуса по составу, гумус верх- 
них горизонтов фульватно-гуматный и постепенно переходит в гуматнофульватный. Этим, очевидно, и объясняется более низкое содержание его в верхних горизонтах и постепенное убывание с глубиной.

Для буроземов типичных характерна ненасыщенность и слабая насыщенность почвенного поглощающего комплекса основаниями (даже в гумусовом горизонте). Распределение общего количества поглощенных оснований имеет преимущественно аккумулятивный характер, что связано как с типом распределения гумуса в этих почвах, так и с преобладающим типом распределения илистой фракции.

Буроземы грубогумусированные (Humic Cambisols (Sceletic)) формируются непосредственно на водораздельных поверхностях, на достаточно крутых склонах под зарослями разновозрастного кедра, независимо от их высоты под дубняками рододендровыми с разреженным травянистым напочвенным покровом, состоящим в основном из осочек, а также в небольших по площади кедровниках мертвопокровных. В этих почвах под мощной многослойной подстилкой лежит органо-аккумулятивный горизонт с присутствием на поверхности серогумусового горизонта грубогумусового материала и с обилием хорошо разложившейся (по типу трухи) органикой. Этот горизонт войлокообразный и густо переплетен живыми корнями. Сам серогумусовый горизонт не имеет хорошо выраженной комковато-зернистой структуры мелкозема, что отмечается у буроземов типичных. Мелкозем этих горизонтов вообще практически не оструктурен, порошистый, в нем присутствуют недоразложившиеся растительные остатки. Как правило, имеется переходный минеральный горизонт, либо полностью прокрашенный гумусом, либо имеющий хорошо выраженные гумусовые затеки.

Содержание гумуса в буроземах грубогумусированных варьирует в широких пределах - от 4 до 10 \% в органо-аккумулятивных горизонтах и до $1 \%$ и менее в нижних горизонтах почвенного профиля. По составу гумус в этих почвах гуматный.

Буроземы оподзоленные (Albic Cambisols) имеют локальное распространение в почвенном покрове заповедника на крутых склонах с березовыми зарослями, являющимися послепожарными сукцессиями, где плоскостной сток преобладает над внутрипочвенным, в результате чего идет осветление нижней части гумусового горизонта, либо в нижних выположенных частях склонов, но на хорошо дренируемых мелкоземисто- 
обломочных отложениях. Почвообразование происходит на щебнистомелкоземистых плотно упакованных покровных отложениях, служащих водоупором при выпадении большого количества осадков в летне-осенний период. Оподзаливание происходит только в почвах, развитых на выветривающемся и переотложенном материале гранитов и проявляется в наличии отмытых светлых зерен минералов в мелкоземе нижней части гумусового горизонта или в верхней части подгумусового, в местах наиболее интенсивного плоскостного или внутрипочвенного стока. Буроземы оподзоленные по реакции среды - кислые и сильнокислые. Содержание гумуса варьирует в широких пределах - от 4 до 10 \% в органо-аккумулятивных горизонтах до 1 \% и менее в нижних горизонтах почвенного профиля. Гумус преимущественно гуматно-фульватного и фульватного состава.

Буроземы темные типичные (Mollic Cambisols (Sceletic)) формируются в нижних частях склонов, по бортам выпуклых гребневидных склонов, пологих склонах, примыкающих к речным долинам и на высоких надпойменных речных террасах под кедрово-широколиственными и широколиственными лесами с густым подлеском (в подросте разновозрастный кедр) на щебнисто-мелкоземистых плотно упакованных покровных отложениях, образующихся в результате процессов выветривания, транспортировки и аккумуляции. Эти отложения очень часто перекрывает аллювиально-пролювиальный материал речных долин. Для буроземов темных типичных характерно наличие подстилки гумифицированного типа мощностью до 7 см. Отличительными морфологическими чертами буроземов темных являются слабая дифференцированность почвенного профиля, мощный гумусово-аккумулятивный горизонт темно-серой, почти черной окраской от 18 до 31 см с хорошо выраженной мелкокомковато-зернистой структурой легко- и среднесуглинистого гранулометрического состава. Четко выраженные переходные горизонты отсутствуют, темноокрашенная толща лежит непосредственно на продуктах выветривания плотных пород, темноокрашенный мелкозем заполняет пустоты между обломками камней.

В буроземах темных типичных реакция среды определяется литогенной основой. Почвы, сформированные на делювиальных отложениях гранитов, как правило, имеют кислую и сильнокислую реакцию среды, у почв, почвообразующей породой которых являются отложения выветривающихся известковых пород или аллювиальные отложения реакция среды слабокислая или близкая к нейтральной. Для буроземов темных ти- 
пичных характерно высокое содержание гумуса во всем почвенном профиле - 16-32 \% в верхних органо-аккумулятивных горизонтах и 5-7 \% в средней части толщи. По составу гумус преимущественно гуматного и фульватно-гуматного состава и только внизу профиля он становится фульватным из-за наличия подвижных фракций гумусовых кислот. Почвы насыщены основаниями, максимум которых приходится на верхние гумусово-аккумулятивные горизонты.

Буроземы темные глееватые (Mollic Clayic Cambisols) pacположены в нижних пологих частях склонов под смешанным лесом с напочвенным покровом, состоящим из осоки (мелкими кочками) и на периферийных частях конусов выноса с вейниковым напочвенным покровом (бассейн реки Проселочная). Эти почвы испытывают значительно большее увлажнение и в морфологическом облике их появляются признаки слабого оглеения, проявляющегося в более плотном подгумусовом горизонте в виде мелких светло-серых пятен.

Буроземы темные остаточно-карбонатные (Mollic Calcaric Cambisols) формируются преимущественно на покровных отложениях известковых пород. Они отличаются более мощными почвенными профилями и наличием до 40 см и более гумусово-аккумулятивного горизонта темносерого или черного цвета, постепенно переходящего в почвообразующую породу. Иллювиально-метаморфический горизонт, наличие которого характерно для буроземов, здесь выражен слабо. Отсутствие четко выраженного иллювиально-метаморфического горизонта и одновременно формирование мощного гумусо-аккумулятивного свидетельствует о развитии в этих почвах преимущественно дернового процесса при слабой выраженности внутрипочвенного оглинивания. Поэтому отнесение их к типу буроземов типичных было бы неверным. Реакция среды определяется литогенной основой почвы. Гуматный состав гумус приобретает не в верхней a, наоборот, в нижней части почвенного профиля. Связано это с повышенным содержанием кальция в этой части профиля, находящегося в не выщелоченных продуктах выветривания известковых пород. Кальций связывает гумусовые кислоты в гуматы, которые теряют свою миграционную способность. Почвы насыщены основаниями, максимум которых приходится на минеральную толщу.

Мелкозем всех вариантов рассматриваемых почв буроземного ряда представлен преимущественно суглинками с невысоким содержанием ила. 
Распределение ила имеет аккумулятивный характер с постепенным уменьшением содержания ила сверху вниз по профилю. Такое распределение ила связано с накоплением тонкодисперсного органического вещества в верхней части профиля, а также с относительно более интенсивно происходящими в этих горизонтах процессами илообразования. Такие особенности в распределении илистой фракции обычно характерны для почв, формирующихся в толще выветривающихся коренных пород. Для почв, развивающихся на перемещенном и погребенном материале коры выветривания (делювий) имеют место другие закономерности в распределении тонкодисперсных фракций, в частности более или менее равномерное распределение их по профилю или даже увеличение в нижней части профиля. Все это достаточно хорошо прослеживается по данным гранулометрического состава. Близкое залегание или выходы коренных пород на поверхность определяют большую щебнистость и каменистость почв.

Валовой химический состав буроземов определяется минералогическим составом почвообразующих пород, так как почвы, сформированные на кислых породах (гранитах), относительно обогащены кремнеземом. Отмечается увеличением его содержания в поверхностных горизонтах, при этом надо отметить, что относительное накопление кремнезема не сопряжено с выносом полуторных окислов (железа и алюминия), а также щелочноземельных элементов из этих горизонтов, следовательно, процесс оподзоливания не проявляется, что подтверждает морфологическая характеристика почв. Профили буроземов, развитые на основных породах, а также на известковых, характеризуются пониженным содержанием кремнезема, что подтверждает связь химического элементного состава мелкозема почв с минералогическим составом почвообразующих пород. В распределении валового алюминия и железа по профилю буроземов наблюдается большое разнообразие. Однако преобладают почвы с одинаковым или возрастающим снизу вверх содержанием алюминия и железа. В распределении щелочноземельных элементов (кальция и магния) отмечается явный аккумулятивный характер, очевидно, эти элементы накапливаются в составе органического вещества, причем преимущество в накоплении характерно для кальция.

Таким образом, данные валового анализа указывают на некоторую особенность в распределении кремнезема, окислов алюминия и железа в профиле буроземов. Почвенный профиль в целом по сравнению с 
условной почвообразующей породой, за которую мы принимаем мелкозем из горизонта материнской породы, обогащается кремнеземом, окислами алюминия и железа. То же самое можно сказать по отношению к кальцию и магнию, они также не выносятся из мелкозема почвенного профиля относительно мелкозема почвообразующей породы и даже относительно накапливаются в верхних горизонтах. Все это противоречит понятиям о процессах внутрипочвенного выветривания и почвообразования, поскольку накопление кремнезема относительно и всегда происходит на фоне выноса каких-то других элементов. Следовательно, для решения вопроса наличия или отсутствия перераспределения соединений кремния, алюминия и железа в профилях исследованных нами буроземов необходимо использовать данные по содержанию этих соединений в породе.

Слаборазвитые почвы - петроземы гумусовые (отдел слаборазвитых почв, ствол первичного почвообразования) (Humic Leptosols) формируются на каменистых развалах, на валунах, реже на скальных обнажениях, под мощной моховой подушкой, лежащей на камнях, под которой находится слой дресвы выветривающейся породы. Тем не менее, процессы почвообразования уже имеют место, поскольку идет накопление органического вещества в нижней части моховой подушки при интенсификации процессов выветривания. По описанию местоположения в рельефе и почвообразующей породы почвы этих участков можно отнести также и к литоземам грубогумусовым (отдел литоземов, ствол постлитогенного почвообразования).

Современная территория старой поймы представлена лугами с редкой кустарниковой растительностью и единичными березами. Почвы этой территории сейчас представлены торфяными и перегнойно-торфянистыми почвами, типичными и оглеенными (Histosols). Почвы современной поймы дерново-аллювиальные типичные и оглеенные, остаточно-пойменные, пойменные слоистые на супесчаном и легко суглинистом аллювии (Fluvisols). Последние еще не совсем вышли из пойменного режима и затапливаются во время сильных паводков, что приводит к формированию слоистых почвенных профилей:

В понижениях прирусловой поймы, под тростниковой и осоковой растительностью, на тяжелосуглинистом аллювии развиты аллювиальные болотные почвы (Histosols). 
Территория морского побережья представлена маршевыми типичными, маршевыми примитивными почвами, маритимными луговыми типичными, маритимными луговыми глеевыми и маритимными луговоболотными почвами (Fluvisols). Это незональные почвы, формирующиеся на сравнительно узкой равнинной прибрежной полосе с травянистой растительностью.

Маршевые почвы формируются непосредственно в прибрежной части устья реки или на приливно-отливной осушке. Маршевые почвы формируются под очень разреженной галофитной растительностью (покрытие до $20 \%$ ), иногда с поверхности располагается фрагментарный слой полуразложившихся водорослей. Морфологически маршевые почвы отличаются друг от друга. Примитивные марши представляют собой стратифицированные минеральные морские отложения, перемежающиеся прослойками полуразложившихся водорослей, в которых даже верхний слой нельзя выделить в качестве генетического горизонта. Однако на этом субстрате произрастает высшая растительность, следовательно, они все-таки являются почвами. Органогенные маршевые почвы имеют уже систему горизонтов, куда входят один или несколько органогенных, сменяющихся с глубиной глеевыми. На низменных, приустьевых участках дельты реки Киевка широко развиты маритимные луговые глеевые, маритимные лугово-болотные и маритимные луговые типичные почвы. К маритимным луговым глеевым и маритимным луговым типичным отнесены почвы, которые в силу каких-то причин вышли из болотного режима и теперь не испытывают постоянного переувлажнения за счет влияния моря. Маритимные луговые глеевые почвы формируются на подножии берегового вала и микропонижениях за ним. Для этих почв характерен грунтово-водный гидроморфизм в нижней части профиля. Растительность на этих почвах разнотравно-осоковая, более густая, чем на маршевых почвах (проективное покрытие до 100 \%). Маритимные луговые типичные почвы данной территории формируются на вершинах береговых валов и на высокой морской террасе, на границе с дубовым лесом. Для данных почв характерен грунтово-водный гидроморфизм подстилающих пород (ниже 1 м) и они испытывают наименьшее влияние моря. Растительность этих почв представляет собой густое разнотравье (проективное покрытие до 100 \% и преобладание галофитных видов). В отличие от маритимных лугово-болотных почв, в которых продолжается накопление 
органики одновременно с процессами педогенеза, в маритимно-луговых типичных минерализация органического материала доминирует над его аккумуляцией. Это приводит к формированию хорошо выраженного дернового горизонта.

Более однообразными по морфологическому строению являются маритимные лугово-болотные почвы. Эти почвы формируются в наиболее пониженных частях прибрежной равнины и за береговым валом. Для данных почв характерен грунтово-водный гидроморфизм с поверхности почвы. Из растительности здесь преобладают мхи (проективное покрытие до 100 \%). Маритимные лугово-болотные почвы обычно состоят из нескольких слоев торфа разной степени разложенности, засоленности и заиленности, которые подстилаются оглеенным минеральным субстратом. Иногда встречаются минеральные прослойки в профиле или тонкий илистый горизонт.

Интересно присутствие в почвенном покрове заповедника полигенетичных профилей почв. Самый современный, верхний почвенный профиль бурозема образовался путем сползания с вышележащего ландшафта. Нижележащие горизонты можно объединить в полициклический профиль серогумусовой на аллювии почвы, когда почвообразование не прерывается в результате крупных многолетних циклов отложения, а цикличность отложения материала приводит к литологической неоднородности в пределах генетических горизонтов.

Закономерности распределения почв обусловлены особенностями рельефа, литологии и растительности (табл.). Все процессы в исследуемых почвах имеют разную степень проявления и разное качественное выражение, что и является, очевидно, причиной пространственного разнообразия как буроземов, так и прибрежных почв на сравнительно небольшой территории. К основным элементарным почвенным процессам, создающим облик современного почвенного профиля почв, относятся гумусоаккумулятивный, процесс иллювиирования и метаморфизации, а также накладывающиеся на основной процессы дернообразования, оглеения, оподзаливания. В прибрежных почвах - это гумусо-аккумулятивный процесс и процесс торфообразования, процессы дернообразования и оглеения являются накладывающимися.

Так как зональными почвами юга Дальнего Востока являются буроземы, то основой их формирования является буроземообразовательный процесс. Для него характерны следующие элементарные почвенные процессы: 
1) гумусообразование и гумусонакопление, ведущие к формированию под подстилкой гумусового горизонта с преобладанием в составе гумуса фульвокислот и бурых гуминовых кислот; 2) сиаллитное оглинивание всей толщи, охваченной почвообразованием, ведущее к формированию глинистометаморфического горизонта $\mathrm{Bm}$ под аккумулятивно-гумусовым горизонтом. Следует отметить, что глинисто-метаморфический горизонт Вm в исследованных почвах имеет двоякое происхождение. В районе маяка на мысе Островном этот горизонт образовался по типу сапролита. В районе озера Чухуненко происхождение иллювиального метаморфического горизонта Bm можно объяснить процессами внутрипочвенного оглинивания (разрушение первичных и синтез вторичных минералов).

Таким образом, высокая динамичность условий почвообразования исследуемого района определяет и высокую мозаичность почвенного покрова на сравнительно небольшой прибрежной полосе шириной до 300 м. Особенно это относится к непосредственно береговой территории, занятой широким спектром почв гидроморфного ряда - маршевых, маритимных, серогумусовых аллювиальных и торфяных почв. Преобладающим типом почв можно назвать бурозем (45 \% от всей исследованной территории), относящуюся к горной территории и маритимные почвы $(27 \%)$, находящиеся на побережье. Морфологические особенности строения почвенных профилей связаны с типом растительности, качеством и количеством растительного опада, рельефом. Так, мощность растительной подстилки максимальна в элювиальных и аккумулятивных ландшафтах, тогда как ее состав и степень разложенности уменьшаются от водораздела к подножию. Преобладание долинной растительности увеличивает интенсивность окраски гумусо-аккумулятивного горизонта и глубину иллювиирования гумусовых веществ вниз по почвенному профилю. Мощность почвенных профилей максимальна в нижних третях склонов северозападной и западной экспозиции, минимальна в средней части склонов южной и юго-восточной экспозиции. Метаморфический горизонт Вm присутствует во всех буроземах, степень выветрелости этого горизонта увеличивается с глубиной. К особенностям процесса буроземообразования на территории заповедника можно отнести присутствие в почвенном профиле глинисто-метаморфического горизонта $\mathrm{Bm}$, образованного в результате сиаллитного оглинивания почвенной толщи. 
Распределение почв на территории Лазовского заповедника

\begin{tabular}{|c|c|c|c|}
\hline \multirow{3}{*}{$\begin{array}{c}\text { Элемент } \\
\text { ландшафта }\end{array}$} & \multicolumn{3}{|c|}{ Почвы } \\
\hline & \multicolumn{2}{|c|}{ Континентальная часть } & Прибрежная часть \\
\hline & Падь Америка & $\begin{array}{c}\text { Падь } \\
\text { Корейская }\end{array}$ & Падь Проселочная \\
\hline \multirow{2}{*}{ Водоразделы } & \multicolumn{2}{|c|}{ Петроземы } & Петроземы \\
\hline & \multicolumn{2}{|c|}{ Буроземы } & Буроземы грубогумусовые \\
\hline $\begin{array}{l}\text { Склоны во- } \\
\text { доразделов }\end{array}$ & \multicolumn{2}{|c|}{ Буроземы } & $\begin{array}{c}\text { Буроземы } \\
\text { Буроземы эродированные }\end{array}$ \\
\hline $\begin{array}{c}\text { Нижняя треть } \\
\text { пологих } \\
\text { склонов }\end{array}$ & \multicolumn{2}{|c|}{$\begin{array}{c}\text { Буроземы } \\
\text { Буроземы глееватые } \\
\text { Буроземы полигенетичные } \\
\text { (буроземы типичные, } \\
\text { сформированные на } \\
\text { погребенной аллювиальной } \\
\text { серогумусовой почве) }\end{array}$} & $\begin{array}{c}\text { Буроземы темногумусовые } \\
\text { Буроземы перегнойно- } \\
\text { темногумусовые }\end{array}$ \\
\hline Долина реки & $\begin{array}{r}\text { Аллювиа } \\
\text { серогумусовы } \\
\text { Псаммоземы }\end{array}$ & $\begin{array}{l}\text { Іьные } \\
\text { типичные } \\
\text { умусовые }\end{array}$ & $\begin{array}{c}\text { Буроземы темногумусовые } \\
\text { Серогумусовые } \\
\text { аллювиальные } \\
\text { Глееземы } \\
\text { перегнойно-гумусовые } \\
\text { Маршевые, маритимные }\end{array}$ \\
\hline
\end{tabular}

\section{Литература}

1. Полевой определитель почв. - М.: Почвенный институт им. В.В. Докучаева, 2008. - 182 с.

2. World Reference Base for Soil Resources 2014, Update 2015. International soil classification system for naming soils and creating legends for soil maps. — 3rd. - Rome: FAO, 2014. 